\title{
SISTEM INFORMASI ADMINISTRASI PADA KELURAHAN KALIDONI KOTA PALEMBANG
}

\author{
Riansyah $^{1}$, Ruliansyah ${ }^{2}$, Sri Rahayu ${ }^{3}$ \\ ${ }^{1}$ Mahasiswa UIN Raden Fatah \\ ${ }^{2}$ Dosen UIN Raden Fatah \\ ${ }^{3}$ Dosen UIN Raden Fatah
}

EMAIL : 1655400115@radenfatah.ac.id, Ruli@radenfatah.ac.id, Srirahayu@ radenfatah.ac.id

\begin{abstract}
Abstrak
Proses layanan administrasi di kelurahan Kalidoni masih dilakukan secara konvensional. Pemohon (penduduk) harus datang sendiri dan dilayani secara manual untuk membuat surat keterangan nikah, surat keterangan tidak mampu, surat keterangan tidak memiliki rumah, surat kematian, surat keterangan usaha, surat KPR rumah, surat izin bangunan, surat pengantar SKCK atau surat keramaian. Penginputan data dan pembuatan layanan surat harus diketik menggunakan aplikasi Microsoft Word dan Microsoft Excel. Pemohon harus datang ke kantor kelurahan Kalidoni untuk membuat dan mengetahui status pengajuan layanan yang diajukannya. Pemohon juga harus bolak balik ke Kantor jika kekurangan syarat untuk pengurusan administrasi sehingga proses pelayanan membutuhkan waktu yang sering kali melebihi standar waktu maksimal yang telah ditetapkan. Kondisi yang sama juga terjadi pada pegawai kelurahan yang mengalami kesulitan dalam memberikan layanan yang maksimal kepada masyarakat. Untuk mengatasi permasalahan tersebut maka dibuatlah sistem informasi administrasi yang berbasis web yang dapat melayani pemohon untuk membuat suratmenyurat. Pembuatan sistem ini menggunakan metode waterfall dengan tahapan analisis kebutuhan, desain sistem, penulisan program, pengujian program, dan penerapan program dan pemeliharaan. Hasil uji implementasi memperlihatkan bahwa sistem yang dibangun dapat membantu pemohon dan pegawai kelurahan dalam proses pembuatan surat-menyurat karena sudah terkomputerisasi sehingga hasil yang didapat lebih cepat dan dapat terdokumentasi lebih baik.
\end{abstract}

Kata Kunci : Layanan Administrasi, Metode Waterfall, Sistem Informasi

\section{PENDAHULUAN}

Pada Peraturan Meteri Dalam Negeri
No.34 tahun 2007 tentang pedoman
administrasi kelurahan BAB 2 pasal II, yaitu
jenis administrasi kelurahan yang terdiri dari
administrasi umum, administrasi
kependudukan, administrasi keuangan,
administrasi pembangunan, dan administrasi
lainnya. Kelurahan Kalidoni yang berada pada
Kecamatan Kalidoni Kota Palembang Provinsi
Sumatera Selatan. Salah satunya pelayanan
secara langsung kepada penduduk yaitu
layanan administrasi berupa surat ket. nikah,
surat ket. tidak mampu, surat ket. tidak
memiliki rumah, surat menikah, surat

kematian, surat ket. usaha, surat KPR rumah, surat izin bangunan, surat pengantar SKCK, dan surat keramaian. Proses pelayanan administrasi kepada masyarakat umumnya masih dilakukan secara konvensional. Penginputan data masyarakat dan pembuatan layanan surat harus diketik melalui aplikasi Microsoft Word dan Microsoft Excel. Pengolahan administrasi kependudukan secara menual memicu beberapa masalah yaitu kerumitan dalam mencari data karena masih tersimpan dalam bentuk dokumen dan pengerjaan informasi memerlukan waktu yang cukup lama karena data dalam format dokumen butuh diproses kembali sebelum di lapokan. Pemohon (masyarakat) harus datang 
ke Kantor Kelurahan Kalidoni Kota Palembang untuk mengetahui prosedur pelayanan administrasi dan mengantri mendapatkan layanan dari instansi pegawai. Selanjutnya sering terjadi juga penduduk melakukan pengajuan di luar jam kerja, misalnya pada waktu jam istirahat dan pulang kerja penduduk masih ada yang minta dilayani. Penduduk juga harus bolak balik ke Kantor apabila ada belum lengkap syarat untuk pengajuan layanan administrasi sehingga proses pelayanan memerlukan durasi yang lama. Rumusan masalah pada penelitian ini adalah bagaimana merancang Sistem Informasi Administrasi Menggunakan Metode Waterfall pada Kelurahan Kalidoni Kota Palembang. Tujuan dari penelitian ini adalah untuk merancang Sistem Informasi Administrasi pada Kelurahan Kalidoni Kota Palembang.

\section{METODE}

Metode yang digunakan pada penelitian ini menggunakan metode waterfall, dengan tahap sebagai berikut: 1). Tahapan analisis kebutuhan adalah mengumpulkan data-data yang berkaitan dengan kebutuhan sistem informasi yang akan dibuat nanti, pada penelitian ini dibutuhkan data-data alur pelayanan administrasi melalui observasi dan wawancara terhadap petugas administrasi. 2). Tahapan desain pada penelitian ini melakukan perancangan kerangka sistem informasi berdasarkan kebutuhan petugas administrasi yang diperoleh dari analisis menggunakan UML yaitu Diagram Class, Diagram Use Case dan Intity Relationship Diagram (ERD). 3). Tahapan pengembangan pada penelitian ini adalah melakukan membangun sistem dengan menggunakan bahasa pemrograman PHP dan menggunakan framework laravel berdasarkan kerangka sistem yang dibuat. 4). Tahapan pengujian sistem nanti menggunakan black box testing pada petugas kantor Kelurahan Kalidoni Kota Palembang dengan instrumen kuisioner. 5). Tahapan pemeliharaan akan dilakukan saat sistem informasi telah rampung dibuat.

\section{HASIL DAN PEMBAHASAN}

\section{Usecase Diagram}

Berikut merupakan Usecase Diagram yang digunakan dalam penelitian ini pada gambar 1.

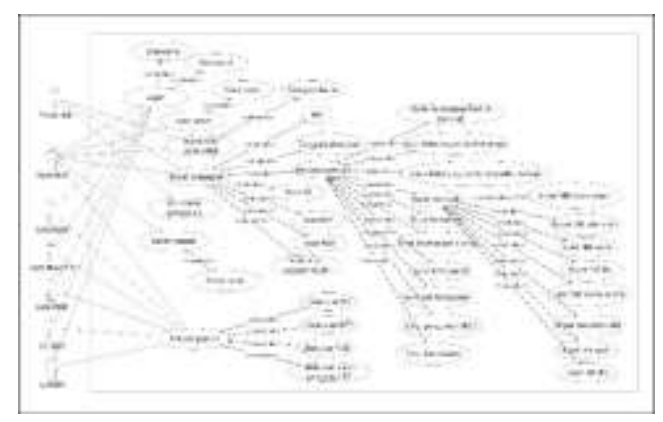

Gambar 1. Usecase Diagram

\section{Entity Relationship Diagram}

Berikut merupakan ERD yang dibangun dalam penelitian ini pada gambar 2 .

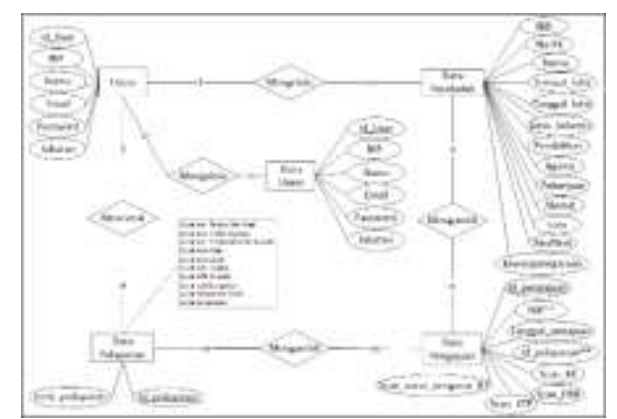

Gambar 2. Entity Relationship Diagram

\section{Desain Antamuka}

Berikut rancangan dari halaman sistem yang dibangun.

\section{a. Rancangan Halaman Beranda}

Rancangan halaman Beranda pertama kali ditampilkan saat membuka website sistem informasi admistrasi pada Kelurahan Kalidoni Kota Palembang.

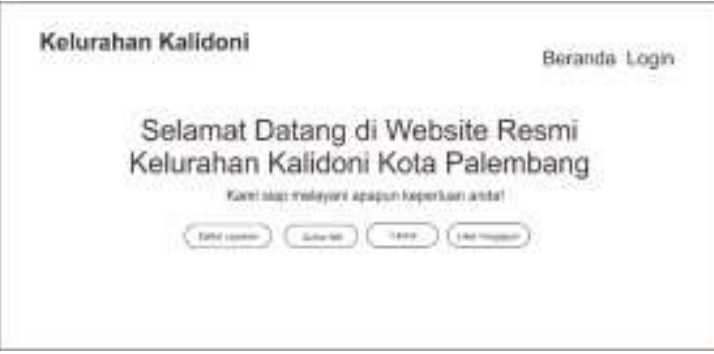


Gambar 3. Rancangan Halaman Beranda

\section{b. Rancangan Halaman Login}

Rancangan halaman login pertama kali ditampilkan pada saat user mengklik button login.

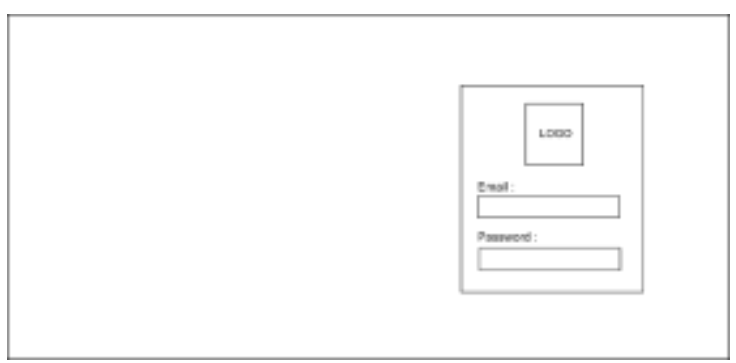

Gambar 4. Rancangan Halamanan Login

\section{c. Rancangan Halaman Tambah Pengajuan Penduduk}

Rancangan halaman tambah pengajuan pada saat Penduduk mengklik button Daftar Layanan.

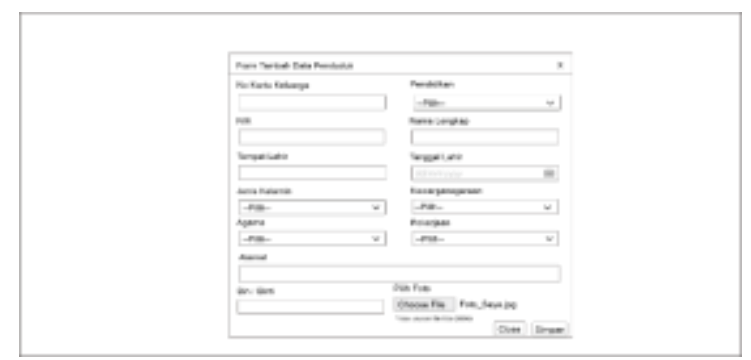

Gambar 5. Rancangan Halaman Tambah Pengajuan Penduduk

\section{d. Rancangan Halaman Tambah Data Penduduk}

Rancangan halaman tambah data penduduk akan ditampilkan pada saat penduduk mengklik button daftar NIK.

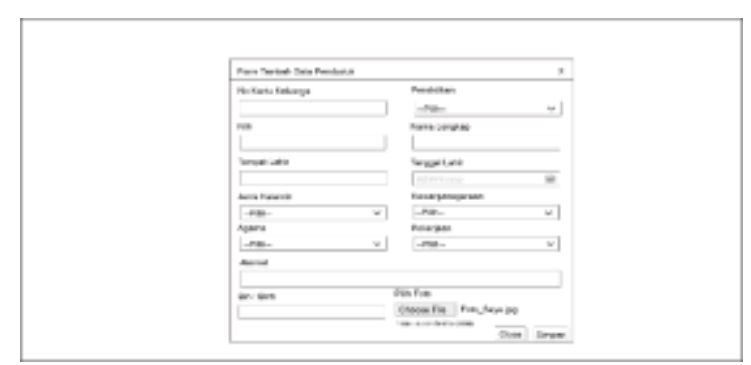

Gambar 6. Rancangan Halaman Tambah Penduduk

\section{e. Rancangan Halaman Cek Pengajuan Layanan Penduduk}

Rancangan halaman cek pengajuan layanan yang ditampilkan penduduk mengklik button cek layanan.

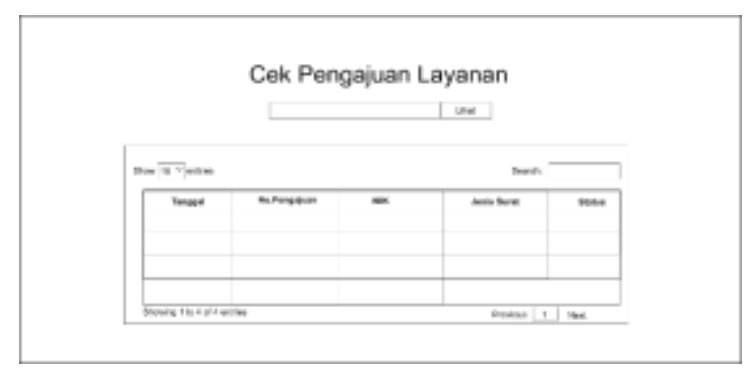

Gambar 7. Rancangan Halaman Cek Pengajuan Penduduk

\section{f. Rancangan Halaman Dashboard Operator}

Berikut ini merupakan halaman utama Operator yang muncul setelah melakukan login.

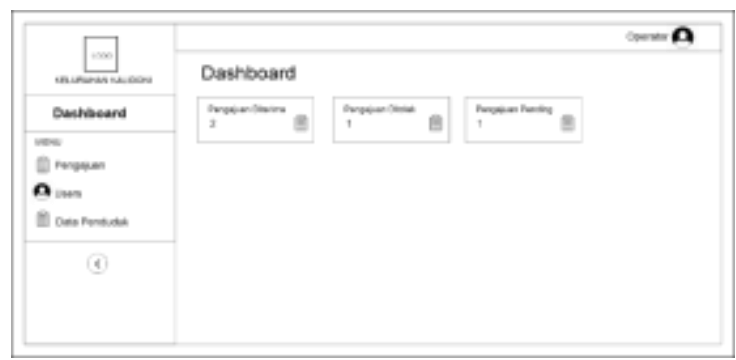

Gambar 8. Rancangan Halaman Dashboard Operator

\section{g. Rancangan Halaman Users Operator}

Rancangan halaman Users pada saat operator memilih menu Users yang ada disamping kiri.

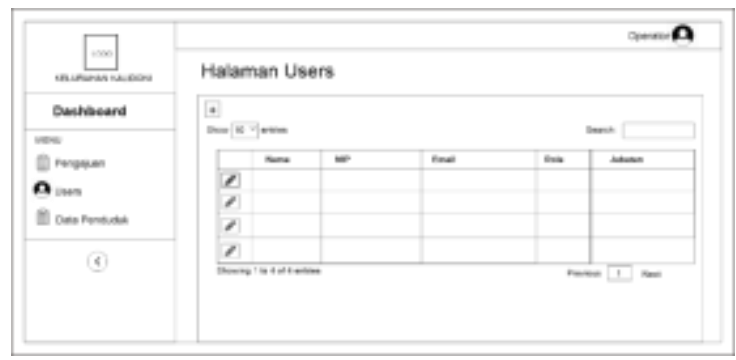


Gambar 9. Rancangan Halaman Users Operator

\section{h. Rancangan Halaman Tambah Users Operator}

Rancangan halaman tambah Users akan ditampilkan pada saat Operator mengklik button tambah users.

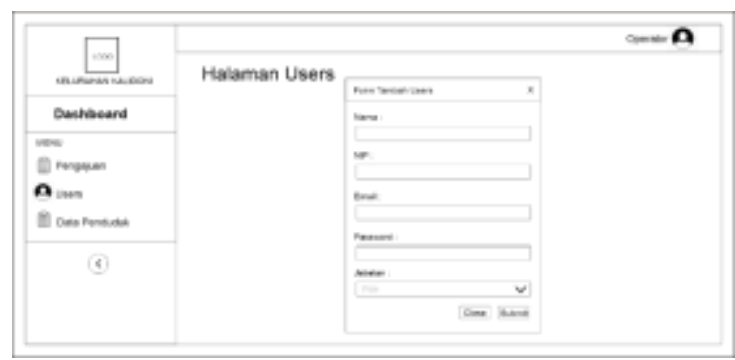

Gambar 10. Rancangan Halaman Tambah Users Operator

\section{i. Rancangan Halaman Edit Users Operator}

Rancangan halaman edit Users akan ditampilkan pada saat Operator mengklik button edit users.

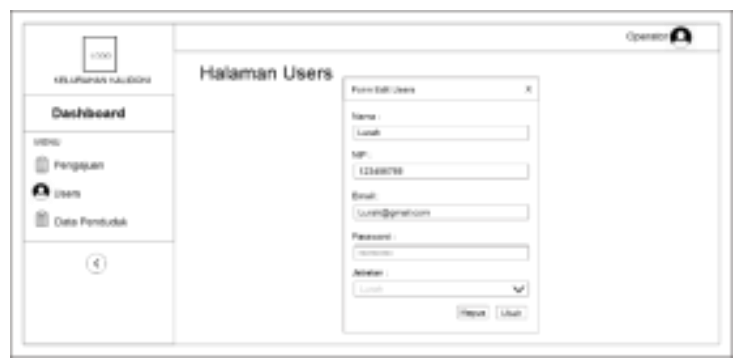

Gambar 11. Rancangan Halaman Edit Users Operator

\section{j. Rancangan Halaman Tambah Pengajuan Operator}

Rancangan halaman tambah pengajuan pada saat Operator memilih menu pengajuan yang ada disamping kiri.

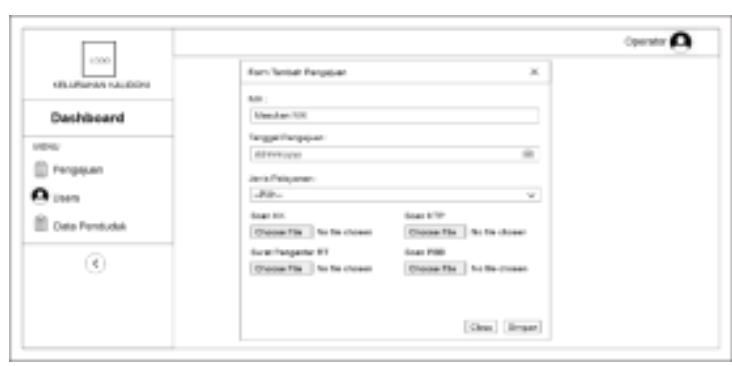

Gambar 12. Rancangan Halaman Tambah Pengajuan Operator

\section{k. Rancangan Halaman Data Penduduk Operator}

Rancangan halaman data penduduk pada saat Operator memilih menu data penduduk yang ada disamping kiri.

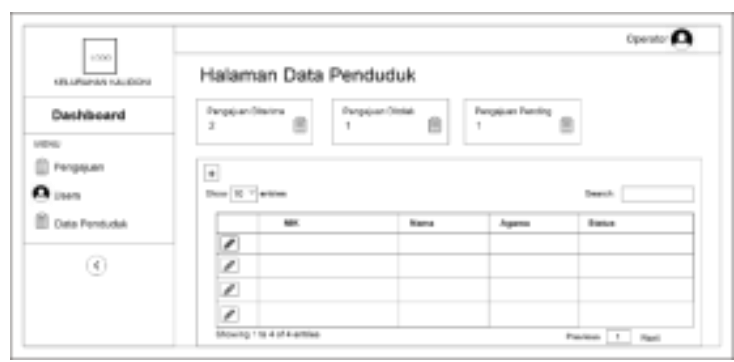

Gambar 13. Rancangan Halaman Data Penduduk Operator

\section{Rancangan Halaman Tambah Data Penduduk Operator}

Rancangan halaman tambah data penduduk akan ditampilkan pada saat Operator mengklik button tambah data penduduk.

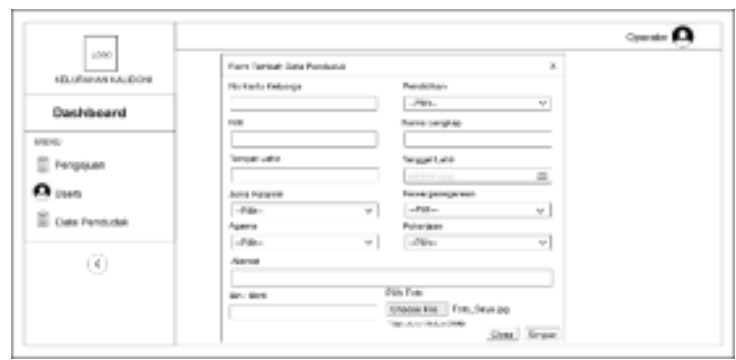

Gambar 14 Rancanan Halaman Tambah Data Penduduk Operator 


\section{m. Rancangan Halaman Print Operator}

Rancangan halaman print akan ditampilkan pada saat Operator mengklik button print.

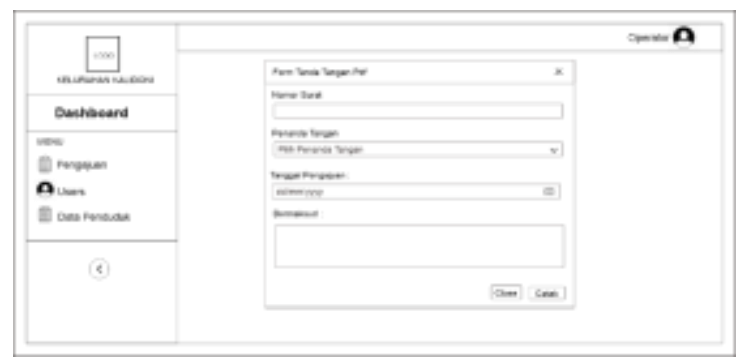

Gambar 15. Rancangan Halaman Print Operator

\section{n. Rancangan Halaman Edit Pengajuan Kasi}

Rancangan halaman edit pengajuan akan ditampilkan pada saat Kasi mengklik button pengajuan.

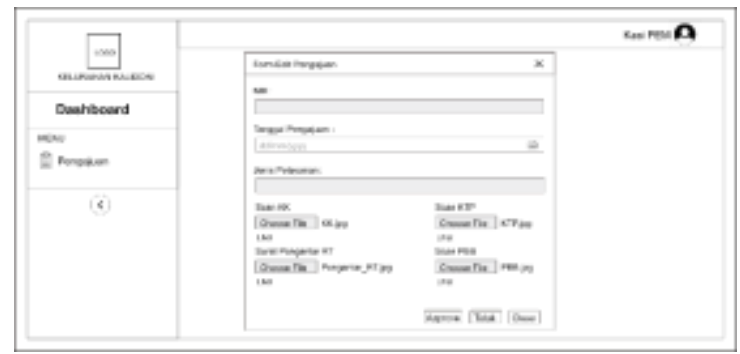

Gambar 16. Rancangan Halaman Edit Pengajuan Kasi

\section{o. Rancangan Halaman Edit Pengajuan Seklur}

Rancangan halaman edit pengajuan akan ditampilkan pada saat Kasi Seklur mengklik button pengajuan.

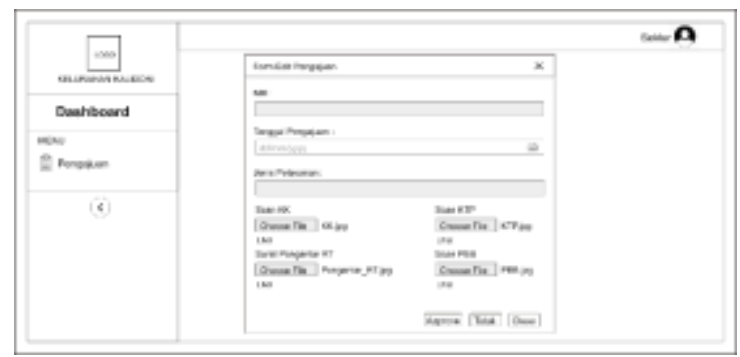

Gambar 17. Rancangan Halaman Edit Pengajuan Seklur

\section{p. Rancangan Halaman Edit Pengajuan Lurah}

Rancangan halaman edit pengajuan akan ditampilkan pada saat Lurah mengklik button pengajuan.

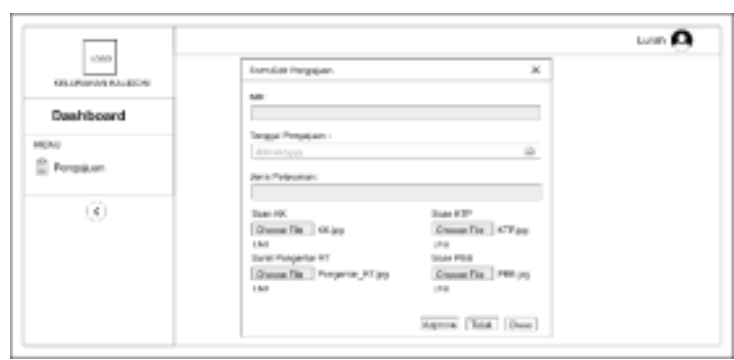

Gambar 18. Rancangan Halaman Edit Pengajuan Lurah

\section{Hasil Antamuka}

\section{a. Tampilan Halaman Beranda}

Berikut ini merupakan tampilan dari halaman Beranda website Kelurahan Kalidoni Kota Palembang.

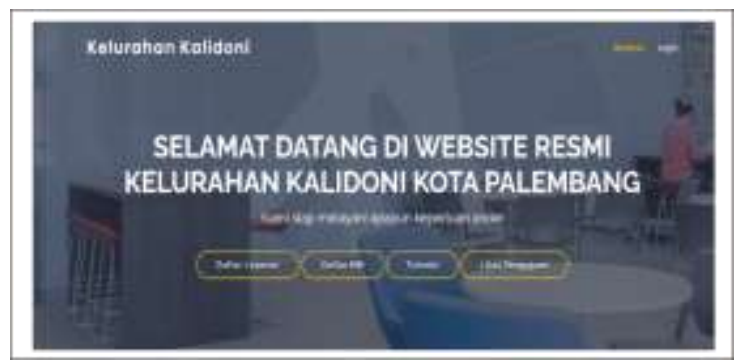

Gambar 21. Tampilan Halaman Beranda

\section{b. Tampilan Halaman Login}

Berikut ini merupakan tampilan dari halaman login yang digunakan untuk setiap Users.

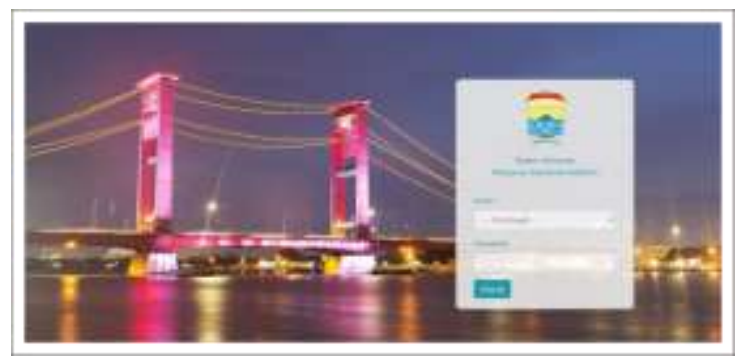

Gambar 22. Tampilan Halaman Login

Teknologi Informasi dan Komunikasi | 124 


\section{c. Tampilan Halaman Tambah Pengajuan Penduduk}

Berikut ini merupakan tampilan halaman pengajuan yang diisi oleh penduduk.

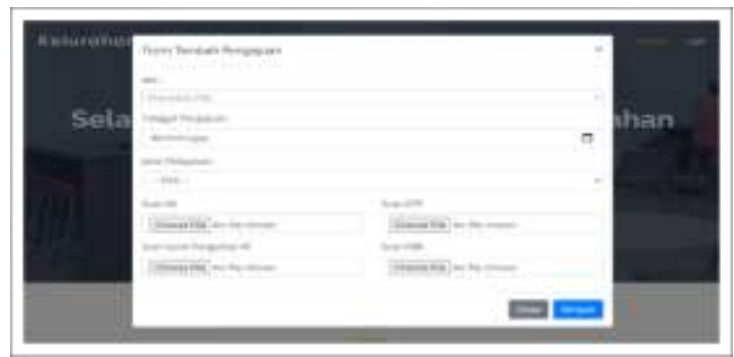

Gambar 23. Tampilan Halaman Tambah Pengajuan Penduduk

\section{d. Tampilan Halaman Tambah Data Penduduk}

Berikut ini merupakan tampilan halaman tambah data penduduk yang diisi oleh penduduk.

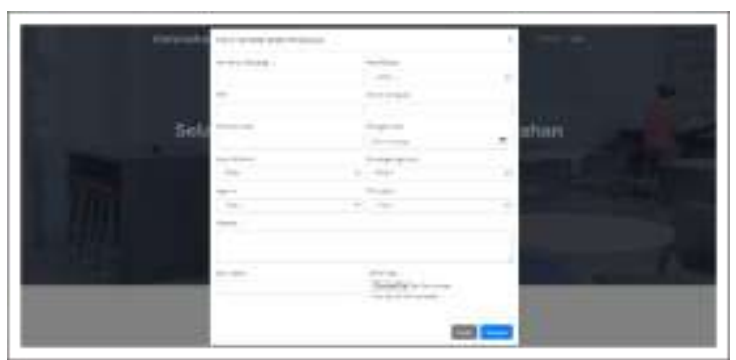

Gambar 24. Tampilan Halaman Tambah Data Penduduk

\section{e. Tampilan Halaman Cek Pengajuan Layanan Penduduk}

Berikut ini merupakan tampilan halaman cek pengajuan layanan yang di cek oleh penduduk.

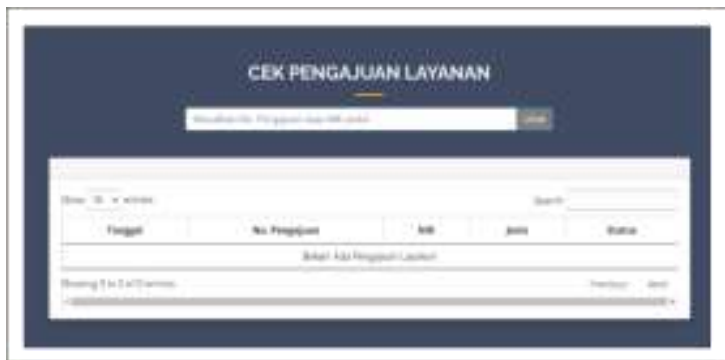

Gambar 25. Tampilan Halaman Cek Pengajuan Layanan Penduduk

\section{f. Tampilan \\ Halaman Dashboard Operator}

Berikut ini merupakan halaman utama Operator yang muncul setelah melakukan login.

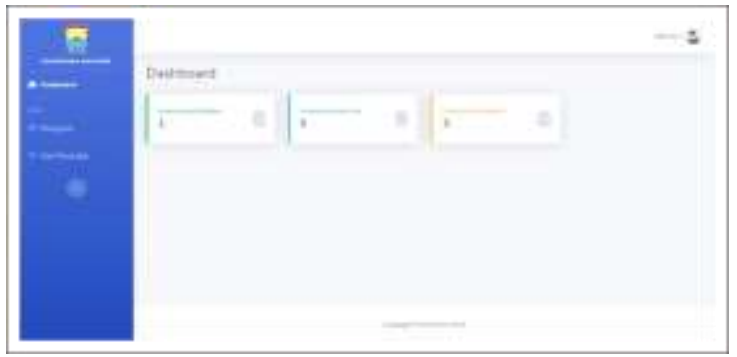

Gambar 26. Tampilan Halaman Dashboaard Operator

\section{g. Tampilan Halaman Users Operator}

Berikut ini merupakan halaman tampilan Users yang dapat dilihat oleh Operator.

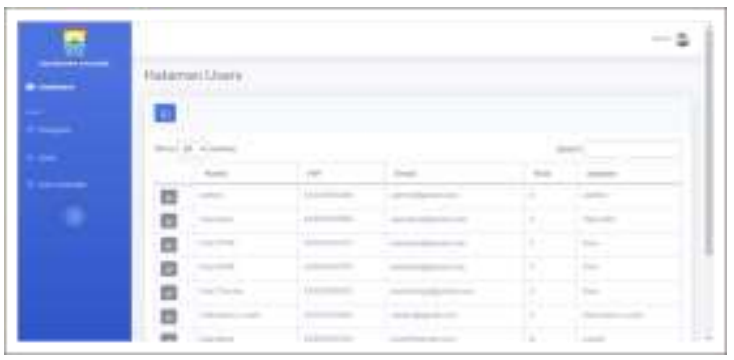

Gambar 27. Tampilan Halaman Users Operator

\section{h. Tampilan Halaman Tambah Users Operator}

Berikut ini merupakan tampilan halaman tambah Users yang dapat dikelola oleh Operator.

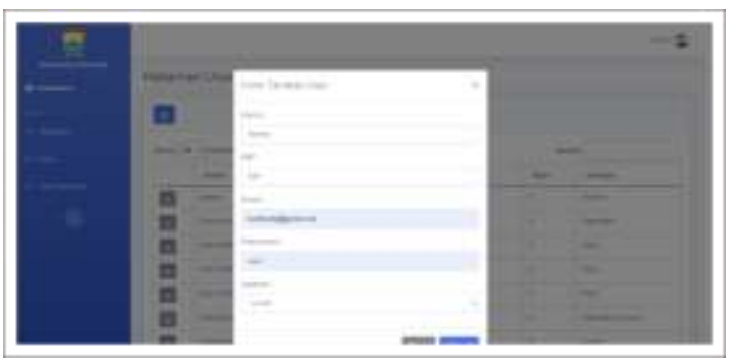


Gambar 28. Tampilan Halaman Tambah Users Operator

i. Tampilan Halaman Edit Users Operator

Berikut ini merupakan tampilan halaman Edit Users yang dapat dikelola oleh Operator.

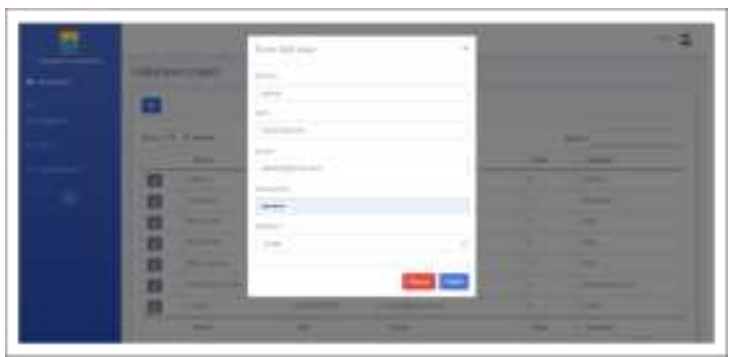

Gambar 29. Tampilan Halaman Edit Users Operator

\section{j. Tampilan Halaman Tambah Pengajuan Operator}

Berikut ini merupakan tampilan halaman pengajuan yang dikelola oleh Operator.

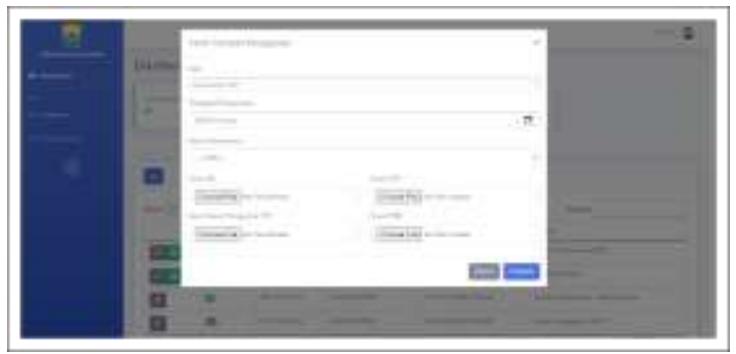

Gambar 30. Tampilan Halaman Tambah Pengajuan operator

\section{k. Tampilan Halaman Data Penduduk Operator}

Berikut ini merupakan tampilan halaman data penduduk yang dilihat oleh Operator.

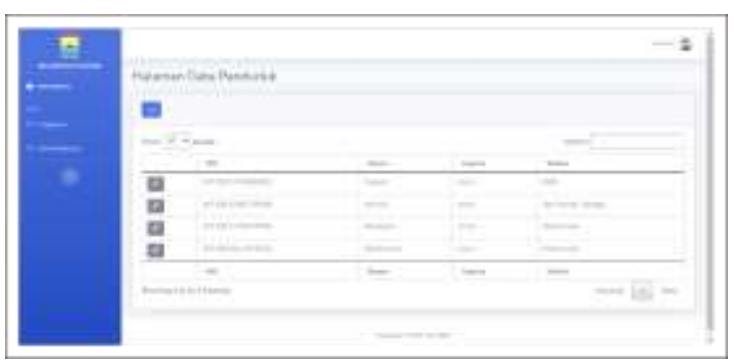

Gambar 31. Tampilan Halaman Data Penduduk Operator

\section{Tampilan Halaman Tambah Data Penduduk Operator}

Berikut ini merupakan tampilan halaman tambah data penduduk yang dikelola oleh Operator.

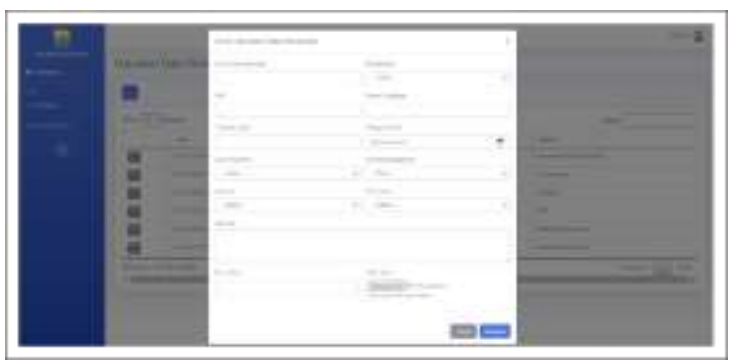

Gambar 32. Tampilan Halaman Tambah Data Penduduk Operator

\section{m. Tampilan Halaman Print Operator}

Berikut ini merupakan tampilan halaman print yang dikelola oleh Operator.

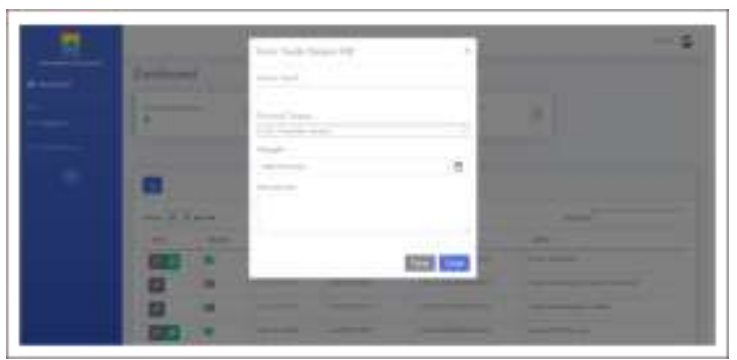

Gambar 33. Tampilan Halaman Print Operator

\section{n. Tampilan Halaman Edit Pengajuan Kasi \\ Berikut ini merupakan halaman edit pengajuan yang dikelola oleh Kasi.}




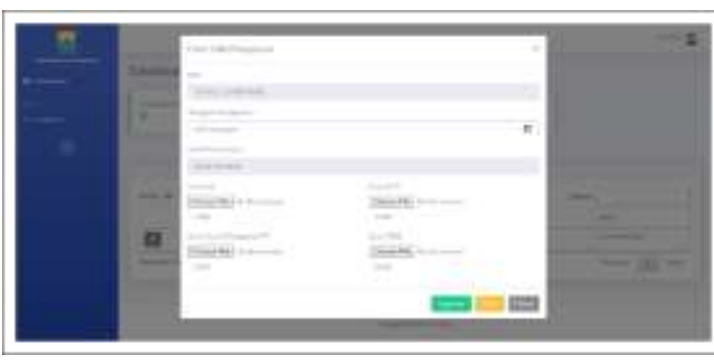

Gambar 34. Tampilan Halaman Edit Pengajuan Kasi

\section{o. Tampilan Halaman Edit Pengajuan Seklur}

Berikut ini merupakan halaman edit pengajuan yang dikelola oleh Seklur.

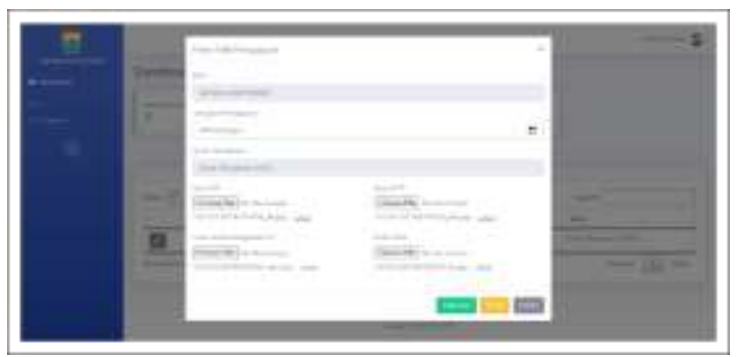

Gambar 35. Tampilan Halaman Edit Pengajuan Seklur

\section{p. Tampilan Halaman Edit Pengajuan Lurah}

Berikut ini merupakan halaman edit pengajuan yang dikelola oleh Lurah.

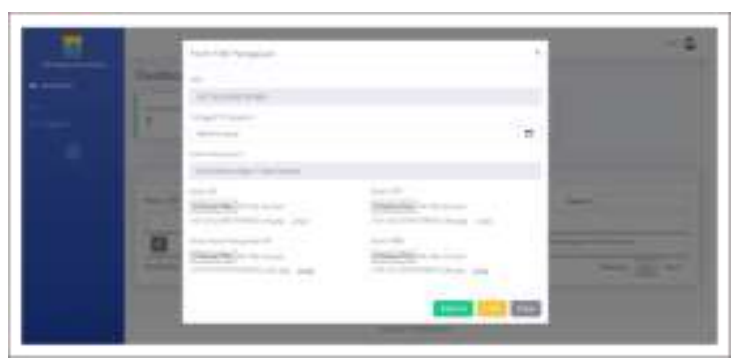

Gambar 36. Tampilan Halaman Edit Pengajuan Lurah

\section{Pengujian Sistem}

Pengujian yang digunakan dalam sistem ini dengan judul Sistem Informasi
Administarasi Menggunakan Metode Waterfall pada Kelurahan Kalidoni Kota Palembang yaitu menggunakan pengujian Black Box yaitu pengujiannya berfokus pada persyaratan fungsional yang dibangun pada sistem ini. Adapun pengujiannya dapat dilihat pada tabel berikut ini.

\section{a. Pengujian Sistem Operator}

Pengujian sistem Operator dilakukan oleh Operator sistem informasi administrasi yang terdiri dari login, menu pengajuan, menu users, menu data penduduk dan logout.

Tabel 1. Pengujan Sistem Operator

\begin{tabular}{|c|c|c|c|c|}
\hline No & Modul & $\begin{array}{c}\text { Persyarata } \\
\text { n }\end{array}$ & $\begin{array}{l}\text { Hasil yang } \\
\text { diharapkan }\end{array}$ & $\begin{array}{c}\text { Hasil } \\
\text { uji } \\
\text { coba }\end{array}$ \\
\hline 1. & Login & $\begin{array}{l}\text { Masukan } \\
\text { username } \\
\text { dan } \\
\text { password } \\
\text { yang telah } \\
\text { terdaftar. }\end{array}$ & $\begin{array}{l}\text { Operator } \\
\text { dapat } \\
\text { mengakses } \\
\text { dashboard } \\
\text { admin }\end{array}$ & $\begin{array}{c}\text { Berhas } \\
\text { il }\end{array}$ \\
\hline 2. & $\begin{array}{l}\text { Lihat } \\
\text { daftar } \\
\text { users }\end{array}$ & $\begin{array}{l}\text { Klik menu } \\
\text { users }\end{array}$ & $\begin{array}{l}\text { Operator } \\
\text { dapat melihat } \\
\text { daftar users }\end{array}$ & $\begin{array}{c}\text { Berhas } \\
\text { il }\end{array}$ \\
\hline 3. & $\begin{array}{l}\text { Tambah } \\
\text { daftar } \\
\text { users }\end{array}$ & $\begin{array}{l}\text { Klik button } \\
\text { tambah } \\
\text { daftar users }\end{array}$ & $\begin{array}{l}\text { Operator } \\
\text { dapat } \\
\text { menambahka } \\
\text { n daftar users }\end{array}$ & $\begin{array}{c}\text { Berhas } \\
\text { il }\end{array}$ \\
\hline 4. & $\begin{array}{l}\text { Close } \\
\text { daftar } \\
\text { users }\end{array}$ & $\begin{array}{l}\text { Klik button } \\
\text { close daftar } \\
\text { user }\end{array}$ & $\begin{array}{l}\text { Operator } \\
\text { dapat } \\
\text { menutup } \\
\text { halaman } \\
\text { tambah users }\end{array}$ & $\begin{array}{c}\text { Berhas } \\
\text { il }\end{array}$ \\
\hline 5. & $\begin{array}{l}\text { Edit } \\
\text { daftar } \\
\text { users }\end{array}$ & $\begin{array}{l}\text { Klik button } \\
\text { edit daftar } \\
\text { users }\end{array}$ & $\begin{array}{l}\text { Operator } \\
\text { dapat } \\
\text { mengubah } \\
\text { daftar users }\end{array}$ & $\begin{array}{c}\text { Berhas } \\
\text { il }\end{array}$ \\
\hline 6. & $\begin{array}{l}\text { Hapus } \\
\text { daftar } \\
\text { users }\end{array}$ & $\begin{array}{l}\text { Klik button } \\
\text { hapus } \\
\text { daftar users }\end{array}$ & $\begin{array}{l}\text { Operator } \\
\text { dapat } \\
\text { menghapus } \\
\text { daftar users }\end{array}$ & $\begin{array}{c}\text { Berhas } \\
\text { il }\end{array}$ \\
\hline 7. & $\begin{array}{l}\text { Search } \\
\text { daftar } \\
\text { users }\end{array}$ & $\begin{array}{l}\text { Klik button } \\
\text { search } \\
\text { daftar users }\end{array}$ & $\begin{array}{l}\text { Operator } \\
\text { mencari data } \\
\text { users }\end{array}$ & $\begin{array}{c}\text { Berhas } \\
\text { il }\end{array}$ \\
\hline 8. & $\begin{array}{l}\text { Lihat } \\
\text { daftar } \\
\text { pengajua } \\
n\end{array}$ & $\begin{array}{l}\text { Klik menu } \\
\text { pengajuan }\end{array}$ & $\begin{array}{l}\text { Operator } \\
\text { dapat melihat } \\
\text { daftar } \\
\text { pengajuan }\end{array}$ & $\begin{array}{c}\text { Berhas } \\
\text { il }\end{array}$ \\
\hline 9. & $\begin{array}{l}\text { Lihat } \\
\operatorname{scan} \mathrm{KK}\end{array}$ & $\begin{array}{l}\text { Klik button } \\
\text { lihat scan } \\
\mathrm{KK}\end{array}$ & $\begin{array}{l}\text { Operator } \\
\text { dapat melihat } \\
\text { file scan KK }\end{array}$ & $\begin{array}{c}\text { Berhas } \\
\text { il }\end{array}$ \\
\hline 10. & $\begin{array}{l}\text { Lihat } \\
\text { scan } \\
\text { KTP }\end{array}$ & $\begin{array}{l}\text { Klik button } \\
\text { lihat scan } \\
\text { KTP }\end{array}$ & $\begin{array}{l}\text { Operator } \\
\text { dapat melihat } \\
\text { file scan KTP }\end{array}$ & $\begin{array}{c}\text { Berhas } \\
\text { il }\end{array}$ \\
\hline 11. & $\begin{array}{l}\text { Lihat } \\
\text { scan } \\
\text { Penganta } \\
\text { r RT }\end{array}$ & $\begin{array}{l}\text { Klik button } \\
\text { lihat scan } \\
\text { Pengantar } \\
\text { RT }\end{array}$ & $\begin{array}{l}\text { Operator } \\
\text { dapat melihat } \\
\text { file scan } \\
\text { Pengantar } \\
\text { RT }\end{array}$ & $\begin{array}{c}\text { Berhas } \\
\text { il }\end{array}$ \\
\hline 12. & $\begin{array}{l}\text { Lihat } \\
\text { scan } \\
\text { PBB }\end{array}$ & $\begin{array}{l}\text { Klik button } \\
\text { lihat scan } \\
\text { PBB }\end{array}$ & $\begin{array}{l}\text { Operator } \\
\text { dapat melihat } \\
\text { file scan PBB }\end{array}$ & $\begin{array}{c}\text { Berhas } \\
\text { il }\end{array}$ \\
\hline
\end{tabular}




\begin{tabular}{|c|c|c|c|c|}
\hline 13. & $\begin{array}{l}\text { Tambah } \\
\text { daftar } \\
\text { pengajua } \\
n\end{array}$ & $\begin{array}{l}\text { Klik button } \\
\text { tambah } \\
\text { daftar } \\
\text { pengajuan }\end{array}$ & $\begin{array}{l}\text { Operator } \\
\text { dapat } \\
\text { menambahka } \\
\text { n daftar } \\
\text { pengajuan }\end{array}$ & $\begin{array}{c}\text { Berhas } \\
\text { il }\end{array}$ \\
\hline 14. & $\begin{array}{l}\text { Tambah } \\
\text { scan KK }\end{array}$ & $\begin{array}{l}\text { Klik button } \\
\text { tambah } \\
\text { scan KK }\end{array}$ & $\begin{array}{l}\text { Operator } \\
\text { dapat } \\
\text { menambahka } \\
\mathrm{n} \text { file scan KK }\end{array}$ & $\begin{array}{c}\text { Berhas } \\
\text { il }\end{array}$ \\
\hline 15. & $\begin{array}{l}\text { Tambah } \\
\text { scan } \\
\text { KTP }\end{array}$ & $\begin{array}{l}\text { Klik button } \\
\text { tambah } \\
\text { scan KTP }\end{array}$ & $\begin{array}{l}\text { Operator } \\
\text { dapat } \\
\text { menambahka } \\
\text { n file scan } \\
\text { KTP }\end{array}$ & $\begin{array}{c}\text { Berhas } \\
\text { il }\end{array}$ \\
\hline 16. & $\begin{array}{l}\text { Tambah } \\
\text { scan } \\
\text { Penganta } \\
\text { r RT }\end{array}$ & $\begin{array}{l}\text { Klik button } \\
\text { tambah } \\
\text { scan } \\
\text { Pengantar } \\
\text { RT }\end{array}$ & $\begin{array}{l}\text { Operator } \\
\text { dapat } \\
\text { menambahka } \\
\mathrm{n} \text { file scan } \\
\text { Pengantar } \\
\text { RT }\end{array}$ & $\begin{array}{c}\text { Berhas } \\
\text { il }\end{array}$ \\
\hline 17. & $\begin{array}{l}\text { Tambah } \\
\text { scan } \\
\text { PBB }\end{array}$ & $\begin{array}{l}\text { Klik button } \\
\text { tambah } \\
\text { scan PBB }\end{array}$ & $\begin{array}{l}\text { Operator } \\
\text { dapat } \\
\text { menambahka } \\
\mathrm{n} \text { file scan } \\
\text { PBB }\end{array}$ & $\begin{array}{c}\text { Berhas } \\
\text { il }\end{array}$ \\
\hline 18. & $\begin{array}{l}\text { Close } \\
\text { daftar } \\
\text { pengajua } \\
n\end{array}$ & $\begin{array}{l}\text { Klik button } \\
\text { close daftar } \\
\text { pengajuan }\end{array}$ & $\begin{array}{l}\text { Operator } \\
\text { dapat } \\
\text { menutup } \\
\text { halaman } \\
\text { tambah } \\
\text { pengajuan }\end{array}$ & $\begin{array}{c}\text { Berhas } \\
\text { il }\end{array}$ \\
\hline 19. & $\begin{array}{l}\text { Edit } \\
\text { daftar } \\
\text { pengajua } \\
n\end{array}$ & $\begin{array}{l}\text { Klik button } \\
\text { edit daftar } \\
\text { pengajuan }\end{array}$ & $\begin{array}{l}\text { Operator } \\
\text { dapat } \\
\text { mengubah } \\
\text { daftar } \\
\text { pengajuan }\end{array}$ & $\begin{array}{c}\text { Berhas } \\
\text { il }\end{array}$ \\
\hline 20. & $\begin{array}{l}\text { Edit scan } \\
\text { KK }\end{array}$ & $\begin{array}{l}\text { Klik button } \\
\text { edit scan } \\
\text { KK }\end{array}$ & $\begin{array}{l}\text { Operator } \\
\text { dapat } \\
\text { mengubah } \\
\text { file scan KK }\end{array}$ & $\begin{array}{c}\text { Berhas } \\
\text { il }\end{array}$ \\
\hline 21. & $\begin{array}{l}\text { Edit scan } \\
\text { KTP }\end{array}$ & $\begin{array}{l}\text { Klik button } \\
\text { edit scan } \\
\text { KTP }\end{array}$ & $\begin{array}{l}\text { Operator } \\
\text { dapat } \\
\text { mengubah } \\
\text { file scan KTP }\end{array}$ & $\begin{array}{c}\text { Berhas } \\
\text { il }\end{array}$ \\
\hline 22. & $\begin{array}{l}\text { Edit scan } \\
\text { Penganta } \\
\text { r RT }\end{array}$ & $\begin{array}{l}\text { Klik button } \\
\text { edit scan } \\
\text { Pengantar } \\
\text { RT }\end{array}$ & $\begin{array}{l}\text { Operator } \\
\text { dapat } \\
\text { mengubah } \\
\text { file scan } \\
\text { Pengantar } \\
\text { RT }\end{array}$ & $\begin{array}{c}\text { Berhas } \\
\text { il }\end{array}$ \\
\hline 23. & $\begin{array}{l}\text { Edit scan } \\
\text { PBB }\end{array}$ & $\begin{array}{l}\text { Klik button } \\
\text { edit scan } \\
\text { PBB }\end{array}$ & $\begin{array}{l}\text { Operator } \\
\text { dapat } \\
\text { mengubah } \\
\text { file scan PBB }\end{array}$ & $\begin{array}{c}\text { Berhas } \\
\text { il }\end{array}$ \\
\hline 24. & $\begin{array}{l}\text { Hapus } \\
\text { daftar } \\
\text { pengajua } \\
n\end{array}$ & $\begin{array}{l}\text { Klik button } \\
\text { hapus } \\
\text { daftar } \\
\text { pengajuan }\end{array}$ & $\begin{array}{l}\text { Operator } \\
\text { dapat } \\
\text { menghapus } \\
\text { pengajuan }\end{array}$ & $\begin{array}{c}\text { Berhas } \\
\text { il }\end{array}$ \\
\hline 25. & $\begin{array}{l}\text { Search } \\
\text { daftar } \\
\text { pengajua } \\
n\end{array}$ & $\begin{array}{l}\text { Klik button } \\
\text { search } \\
\text { daftar } \\
\text { pengajuan }\end{array}$ & $\begin{array}{l}\text { Operator } \\
\text { mencari data } \\
\text { pengajuan }\end{array}$ & $\begin{array}{c}\text { Berhas } \\
\text { il }\end{array}$ \\
\hline 26. & $\begin{array}{l}\text { Print } \\
\text { daftar } \\
\text { pengajua } \\
\mathrm{n}\end{array}$ & $\begin{array}{l}\text { Klik button } \\
\text { print daftar } \\
\text { pengajuan }\end{array}$ & $\begin{array}{l}\text { Operator } \\
\text { dapat } \\
\text { mencetak } \\
\text { daftar } \\
\text { pengajuan }\end{array}$ & $\begin{array}{c}\text { Berhas } \\
\text { il }\end{array}$ \\
\hline 27. & $\begin{array}{l}\text { Lihat } \\
\text { daftar } \\
\text { data } \\
\text { pendudu }\end{array}$ & $\begin{array}{l}\text { Klik menu } \\
\text { data } \\
\text { penduduk }\end{array}$ & $\begin{array}{l}\text { Operator } \\
\text { dapat melihat } \\
\text { daftar data } \\
\text { penduduk }\end{array}$ & $\begin{array}{c}\text { Berhas } \\
\text { il }\end{array}$ \\
\hline
\end{tabular}

\begin{tabular}{|c|c|c|c|c|}
\hline & $\mathrm{k}$ & & & \\
\hline 28. & $\begin{array}{l}\text { Tambah } \\
\text { daftar } \\
\text { data } \\
\text { pendudu } \\
\mathrm{k} \\
\end{array}$ & $\begin{array}{l}\text { Klik button } \\
\text { tambah } \\
\text { daftar data } \\
\text { penduduk }\end{array}$ & $\begin{array}{l}\text { Operator } \\
\text { dapat } \\
\text { menambahka } \\
\text { n daftar data } \\
\text { penduduk }\end{array}$ & $\begin{array}{c}\text { Berhas } \\
\text { il }\end{array}$ \\
\hline 29. & $\begin{array}{l}\text { Upload } \\
\text { data foto } \\
\text { pendudu } \\
\mathrm{k}\end{array}$ & $\begin{array}{l}\text { Klik button } \\
\text { upload data } \\
\text { foto } \\
\text { penduduk }\end{array}$ & $\begin{array}{l}\text { Operator } \\
\text { dapat } \\
\text { mengungah } \\
\text { data foto } \\
\text { penduduk }\end{array}$ & $\begin{array}{c}\text { Berhas } \\
\text { il }\end{array}$ \\
\hline 30. & $\begin{array}{l}\text { Edit } \\
\text { daftar } \\
\text { data } \\
\text { pendudu } \\
\mathrm{k} \\
\end{array}$ & $\begin{array}{l}\text { Klik button } \\
\text { edit daftar } \\
\text { data } \\
\text { penduduk }\end{array}$ & $\begin{array}{l}\text { Operator } \\
\text { dapat } \\
\text { mengubah } \\
\text { daftar data } \\
\text { penduduk }\end{array}$ & $\begin{array}{c}\text { Berhas } \\
\text { il }\end{array}$ \\
\hline 31. & $\begin{array}{l}\text { Hapus } \\
\text { daftar } \\
\text { data } \\
\text { pendudu } \\
\mathrm{k}\end{array}$ & $\begin{array}{l}\text { Klik button } \\
\text { hapus } \\
\text { daftar data } \\
\text { penduduk }\end{array}$ & $\begin{array}{l}\text { Operator } \\
\text { dapat } \\
\text { menghapus } \\
\text { daftar data } \\
\text { penduduk }\end{array}$ & $\begin{array}{c}\text { Berhas } \\
\text { il }\end{array}$ \\
\hline 32. & $\begin{array}{l}\text { Close } \\
\text { daftar } \\
\text { data } \\
\text { pendudu } \\
\mathrm{k} \\
\end{array}$ & $\begin{array}{l}\text { Klik button } \\
\text { close daftar } \\
\text { data } \\
\text { penduduk }\end{array}$ & $\begin{array}{l}\text { Operator } \\
\text { dapat } \\
\text { menutup } \\
\text { daftar data } \\
\text { penduduk }\end{array}$ & $\begin{array}{c}\text { Berhas } \\
\text { il }\end{array}$ \\
\hline 33. & Logout & $\begin{array}{l}\text { Klik menu } \\
\text { logout }\end{array}$ & $\begin{array}{l}\text { Operator } \\
\text { keluar dari } \\
\text { Halaman } \\
\text { Admin }\end{array}$ & $\begin{array}{c}\text { Berhas } \\
\text { il }\end{array}$ \\
\hline
\end{tabular}

\section{b. Pengujian Sistem Seklur}

Pengujian sistem Seklur dilakukan oleh Seklur sistem informasi administrasi yang terdiri dari login, menu pengajuan, dan logout.

Tabel 5. Pengujian Sistem Seklur

\begin{tabular}{|c|c|c|c|c|}
\hline $\begin{array}{c}\text { No } \\
\text {. }\end{array}$ & Modul & $\begin{array}{c}\text { Persyarata } \\
\mathbf{n}\end{array}$ & $\begin{array}{c}\text { Hasil yang } \\
\text { diharapka } \\
\mathbf{n}\end{array}$ & $\begin{array}{c}\text { Hasil } \\
\text { uji } \\
\text { coba }\end{array}$ \\
\hline 1. & Login & $\begin{array}{l}\text { Masukan } \\
\text { username } \\
\text { dan } \\
\text { password } \\
\text { yang telah } \\
\text { terdaftar. }\end{array}$ & $\begin{array}{l}\text { Seklur } \\
\text { dapat } \\
\text { mengakses } \\
\text { dashboard } \\
\text { Seklur. }\end{array}$ & $\begin{array}{c}\text { Berhasi } \\
\text { I }\end{array}$ \\
\hline 2. & $\begin{array}{l}\text { Lihat } \\
\text { daftar } \\
\text { pengajua } \\
n\end{array}$ & $\begin{array}{l}\text { Klik menu } \\
\text { pengajuan }\end{array}$ & $\begin{array}{l}\text { Seklur } \\
\text { dapat } \\
\text { melihat } \\
\text { daftar } \\
\text { pengajuan }\end{array}$ & $\begin{array}{c}\text { Berhasi } \\
\text { I }\end{array}$ \\
\hline 3. & $\begin{array}{l}\text { Edit daftar } \\
\text { pengajua } \\
\mathrm{n}\end{array}$ & $\begin{array}{l}\text { Klik button } \\
\text { edit daftar } \\
\text { pengajuan }\end{array}$ & $\begin{array}{l}\text { Seklur } \\
\text { dapat } \\
\text { mengedit } \\
\text { daftar } \\
\text { pengajuan }\end{array}$ & $\begin{array}{c}\text { Berhasi } \\
\text { I }\end{array}$ \\
\hline 4. & $\begin{array}{l}\text { Lihat scan } \\
\text { KK }\end{array}$ & $\begin{array}{l}\text { Klik button } \\
\text { lihat scan } \\
\text { KK }\end{array}$ & $\begin{array}{l}\text { Seklur } \\
\text { dapat } \\
\text { melihat file } \\
\text { scan KK }\end{array}$ & $\begin{array}{c}\text { Berhasi } \\
\text { I }\end{array}$ \\
\hline 5. & $\begin{array}{l}\text { Lihat scan } \\
\text { KTP }\end{array}$ & $\begin{array}{l}\text { Klik button } \\
\text { lihat scan } \\
\text { KTP }\end{array}$ & $\begin{array}{l}\text { Seklur } \\
\text { dapat } \\
\text { melihat file }\end{array}$ & $\begin{array}{c}\text { Berhasi } \\
\text { I }\end{array}$ \\
\hline
\end{tabular}




\begin{tabular}{|l|l|l|l|c|}
\hline & & & scan KTP & \\
\hline 6. & $\begin{array}{l}\text { Lihat scan } \\
\text { Penganta } \\
\text { r RT }\end{array}$ & $\begin{array}{l}\text { Klik button } \\
\text { lihat scan } \\
\text { Pengantar } \\
\text { RT }\end{array}$ & $\begin{array}{l}\text { Seklur } \\
\text { dapat } \\
\text { melihat file } \\
\text { scan } \\
\text { Pengantar } \\
\text { RT }\end{array}$ & $\begin{array}{c}\text { Berhasi } \\
\text { I }\end{array}$ \\
\hline 7. & $\begin{array}{l}\text { Lihat scan } \\
\text { PBB }\end{array}$ & $\begin{array}{l}\text { Klik button } \\
\text { lihat scan } \\
\text { PBB }\end{array}$ & $\begin{array}{l}\text { Seklur } \\
\text { dapat } \\
\text { melihat file } \\
\text { scan PBB }\end{array}$ & $\begin{array}{c}\text { Berhasi } \\
\text { I }\end{array}$ \\
\hline 8. & $\begin{array}{l}\text { Approve } \\
\text { pengajua }\end{array}$ & $\begin{array}{l}\text { Klik button } \\
\text { approve } \\
\text { pengajuan }\end{array}$ & $\begin{array}{l}\text { Seklur } \\
\text { dapat } \\
\text { mensetuji } \\
\text { pengajuan }\end{array}$ & $\begin{array}{c}\text { Berhasi } \\
\text { I }\end{array}$ \\
\hline 10. & $\begin{array}{l}\text { Tolak } \\
\text { pengajua } \\
\mathrm{n}\end{array}$ & $\begin{array}{l}\text { Klik button } \\
\text { tolak } \\
\text { pengajuan }\end{array}$ & $\begin{array}{l}\text { Seklur } \\
\text { dapar } \\
\text { menolak } \\
\text { pengajuan }\end{array}$ & $\begin{array}{c}\text { Berhasi } \\
\text { I }\end{array}$ \\
\hline 11. & $\begin{array}{l}\text { Logout } \\
\text { Klik menu } \\
\text { logout }\end{array}$ & $\begin{array}{l}\text { Seklur } \\
\text { keluar dari } \\
\text { halaman } \\
\text { Seklur }\end{array}$ & $\begin{array}{c}\text { Berhasi } \\
\text { I }\end{array}$ \\
\hline
\end{tabular}

\section{c. Pengujian Sistem Lurah}

Pengujian sistem Lurah dilakukan oleh Lurah sistem informasi administrasi yang terdiri dari login, menu pengajuan, dan logout.

Tabel 6. Pengujian Sistem Lurah

\begin{tabular}{|c|c|c|c|c|}
\hline No & Modul & $\begin{array}{c}\text { Persyarata } \\
\text { n }\end{array}$ & $\begin{array}{c}\text { Hasil yang } \\
\text { diharapka } \\
n\end{array}$ & $\begin{array}{c}\text { Hasil } \\
\text { uji } \\
\text { coba }\end{array}$ \\
\hline 1. & Login & $\begin{array}{l}\text { Masukan } \\
\text { username } \\
\text { dan } \\
\text { password } \\
\text { yang telah } \\
\text { terdaftar. }\end{array}$ & $\begin{array}{l}\text { Lurah } \\
\text { dapat } \\
\text { mengakses } \\
\text { halaman } \\
\text { dashboard } \\
\text { Lurah. }\end{array}$ & $\begin{array}{c}\text { Berhasi } \\
\text { I }\end{array}$ \\
\hline 2. & $\begin{array}{l}\text { Lihat } \\
\text { daftar } \\
\text { pengajua } \\
n\end{array}$ & $\begin{array}{l}\text { Klik menu } \\
\text { pengajuan }\end{array}$ & $\begin{array}{l}\text { Lurah } \\
\text { dapat } \\
\text { melihat } \\
\text { daftar } \\
\text { pengajuan }\end{array}$ & $\begin{array}{c}\text { Berhasi } \\
\text { I }\end{array}$ \\
\hline 3. & $\begin{array}{l}\text { Edit daftar } \\
\text { pengajua } \\
n\end{array}$ & $\begin{array}{l}\text { Klik button } \\
\text { edit daftar } \\
\text { pengajuan }\end{array}$ & $\begin{array}{l}\text { Lurah } \\
\text { dapat } \\
\text { mengedit } \\
\text { daftar } \\
\text { pengajuan }\end{array}$ & $\begin{array}{c}\text { Berhasi } \\
\text { I }\end{array}$ \\
\hline 4. & $\begin{array}{l}\text { Lihat scan } \\
\text { KK }\end{array}$ & $\begin{array}{l}\text { Klik button } \\
\text { lihat scan } \\
\text { KK }\end{array}$ & $\begin{array}{l}\text { Lurah } \\
\text { dapat } \\
\text { melihat file } \\
\text { scan KK }\end{array}$ & $\begin{array}{c}\text { Berhasi } \\
\text { I }\end{array}$ \\
\hline 5. & $\begin{array}{l}\text { Lihat scan } \\
\text { KTP }\end{array}$ & $\begin{array}{l}\text { Klik button } \\
\text { lihat scan } \\
\text { KTP }\end{array}$ & $\begin{array}{l}\text { Lurah } \\
\text { dapat } \\
\text { melihat file } \\
\text { scan KTP }\end{array}$ & $\begin{array}{c}\text { Berhasi } \\
\text { I }\end{array}$ \\
\hline 6. & $\begin{array}{l}\text { Lihat scan } \\
\text { Penganta } \\
\text { r RT }\end{array}$ & $\begin{array}{l}\text { Klik button } \\
\text { lihat scan } \\
\text { Pengantar } \\
\text { RT }\end{array}$ & $\begin{array}{l}\text { Lurah } \\
\text { dapat } \\
\text { melihat file } \\
\text { scan } \\
\text { Pengantar } \\
\text { RT }\end{array}$ & $\begin{array}{c}\text { Berhasi } \\
\text { I }\end{array}$ \\
\hline
\end{tabular}

\begin{tabular}{|c|l|l|l|c|}
\hline 7. & $\begin{array}{l}\text { Lihat scan } \\
\text { PBB }\end{array}$ & $\begin{array}{l}\text { Klik button } \\
\text { lihat scan } \\
\text { PBB }\end{array}$ & $\begin{array}{l}\text { Lurah } \\
\text { dapat } \\
\text { melihat file } \\
\text { scan PBB }\end{array}$ & $\begin{array}{c}\text { Berhasi } \\
\text { I }\end{array}$ \\
\hline 8. & $\begin{array}{l}\text { Approve } \\
\text { pengajua } \\
\mathrm{n}\end{array}$ & $\begin{array}{l}\text { Klik button } \\
\text { approve } \\
\text { pengajuan }\end{array}$ & $\begin{array}{l}\text { Lurah } \\
\text { dapat } \\
\text { mensetuji } \\
\text { pengajuan }\end{array}$ & $\begin{array}{c}\text { Berhasi } \\
\text { I }\end{array}$ \\
\hline 10. & $\begin{array}{l}\text { Tolak } \\
\text { pengajua } \\
\mathrm{n}\end{array}$ & $\begin{array}{l}\text { Klik button } \\
\text { tolak } \\
\text { pengajuan }\end{array}$ & $\begin{array}{l}\text { Lurah } \\
\text { dapar } \\
\text { menolak } \\
\text { pengajuan }\end{array}$ & $\begin{array}{c}\text { Berhasi } \\
\text { I }\end{array}$ \\
\hline 11. & Logout & $\begin{array}{l}\text { Klik menu } \\
\text { logout }\end{array}$ & $\begin{array}{l}\text { Lurah } \\
\text { keluar dari } \\
\text { halaman } \\
\text { Lurah }\end{array}$ & $\begin{array}{c}\text { Berhasi } \\
\text { I }\end{array}$ \\
\hline
\end{tabular}

\section{KESIMPULAN}

Berdasarkan penelitian dengan judul Sistem Informasi Administrasi Menggunakan Metode Waterfall Pada Kelurahan Kalidoni Kota Palembang maka dapat diambil kesimpulan adalah sistem informasi administrasi ini dibangun dengan menggunakan bahasa pemrograman PHP yang menggunakan framework Laravel dan MySQL sebagai database serta untuk metode pengembangan sistemnya menggunakan metode Waterfall. Sistem informasi administrasi ini dapat membantu serta mempermudah pegawai pengolahan keadministrasian yaitu pengolahan surat dan pengolahan data penduduk.

\section{REFERENSI}

Aminudin. (2015). Cara Efektif Belajar Framework Laravel. Ilmu Teknologi Informasi, 1-28.

Arwaz, A. A., Kusumawijaya, T., Putra, R., Putra, K., \& Saifudin, A. (2019). Pengujian Black Box pada Aplikasi Sistem Seleksi Pemenang Tender Menggunakan Teknik Equivalence Partitions. Jurnal Teknologi Sistem Informasi Dan Aplikasi, 2(4), 130. https://doi.org/10.32493/jtsi.v2i4.3708

Defi, A., \& Siska, I. (2015). Sistem Informasi Pengarsipan Surat Masuk Dan Surat Keluar Pada Kantor Kecamatan Pringkuku. Indonesian Journal on Networking and Security.

Febriantyo, G. R., \& Purwatiningtyas. (2018). 
Rancang Bangun Sistem Informasi Administrasi Kelurahan Mugassari Semarang Berbasis WEB. Prosiding SENDI_U 2018,334-340.

Galih. Surono, N. N. P. (2020). Journal of technology information. Http://Jurnal.Kampuswiduri.Ac.Id/, 5(1), 25-30.

http://jurnal.kampuswiduri.ac.id/index.ph p/infoteh/article/view/79/67

Hariyanto, B. (2018). Dasar Informatika \& Ilmu Komputer Disertai Aksi-aksi Praktis (Pertama). Graha Ilmu.

Herlyviana, D. E., Januarita, D., \& Priyanto, A. (2018). Perancangang Sistem Informasi Pelayanan Administrasi Kelurahan Karangklesem Dengan Metode Prototyping. Seminar Nasional Teknologi Informasi Dan Multimedia 2018, 169-174.

Imaniawan. (2017). Sistem Informasi Administrasi Kependudukan Berbasis Web Pada Desa Bogangin Sumpiuh. Indonesian Journal on Networking and Security, 7(3), 1-9.

Pressman. (2012). Rekayasa Perangkat Lunak. Yogyakarta: Andi.

Putra, D. W. T., \& Andriani, R. (2019). Unified Modelling Language (UML) dalam Perancangan Sistem Informasi Permohonan Pembayaran Restitusi SPPD. Jurnal TeknoIf, 7(1), 32. https://doi.org/10.21063/jtif.2019.v7.1.32 $-39$

Putra, I. G. N. ., Satwika, I. P., \& Putra, I. G. J. . (2020). Rancang Bangun Sistem Informasi Manajemen Administrasi Desa Berbasis Web Menggunakanan Framework Laravel. Jutisi: Jurnal Ilmiah Teknik Informatika Dan Sistem Informasi, 9(2), 163-172.

Romney, M. B., \& Steinbart, P. J. (2015). Sistem Informasi Akuntansi, Edisi 13. Salemba Empat, Jakarta.

Saputra, C., \& Effiyaldi. (2017). Analisis dan Perancangan Sistem Informasi Administrasi Kependudukan Pada Desa Kota Karang. Manajemen Sistem Informasi, 2, No.3(3), 592-609.

Sugiyono. (2009). Metode Penelitian Pendidikan Pendekatan Kuantitatif, Kualitatif dan $R \& D$. Alfabeta.

Wahyuni, R., Marwati, L., Muhaimin, A., Informatika, T., \& Informasi, S. (2020). Sistem Informasi Administrasi Desa Pangkalan Batang di Kecamatan Bengkalis Menggunakan Framework Laravel. 6(2), 107-115.

Widjaja. (2017). Pemerintahan Desa dan Administrasi Desa (Ketiga). Jakarta: Raja Grafindo Persada. 